\title{
AOR
}

Selected Papers of \#AoIR2020:

The $21^{\text {st }}$ Annual Conference of the

Association of Internet Researchers

Virtual Event / 27-31 October 2020

\section{THERE ARE MALE TEARS IN THAT COMMENT SECTION. THE DISCURSIVE NEGOTIATION OF MASCULINITY IN ITALIAN ONLINE MEN'S GROUPS}

\author{
Manolo Farci \\ University of Urbino Carlo Bo
}

\section{Introduction}

In the past ten years there have been intense debates in masculinity studies about transformations in men's behavior and their impact on gender relations. Nowadays, a significant part of these debates is dedicated to trying to understand how white heterosexual masculinities are produced and buttressed in Internet settings, as demonstrated by the increasing amount of works on the heterogeneous nature of the socalled Manosphere. A lot of these studies rely on the premise that men's engagement with masculine practices can be categorized into a set of typologies that shape and structure their experiences and explain their practices and behaviors. In this setting, the use of theoretical concepts such as hegemonic masculinity, hybrid masculinities, toxic masculinity, inclusive masculinity has provided an opportunity to see how the articulations of masculinity are always related to the broader systemic social structures and discourses that work to shape it. While these critical perspectives have been important in drawing attention to men's oppressive practices across many different domains of social life, the assumption of masculinity as an overall governing force of men's behaviors has led to overlooking how subject positioning is always constructed and negotiated in multiple and contradictory discourses that are not easily captured by structurally oriented frameworks such as hegemonic or toxic masculinity (Wailing 2019; Berggren 2014; Beasley 2012).

In response to the accumulated points of criticism against the limits of any structural theorization, the recent third development in men's critical studies of masculinity has

Farci, M. (2020, October). There's Male Tears In That Comment Section. The Discursive Negotation in Italian Online Men's Groups. Paper presented at AoIR 2020: The 21 $1^{\text {th }}$ Annual Conference of the Association of Internet Researchers. Virtual Event: AolR. Retrieved from http://spir.aoir.org. 
sought to completely overhaul the idea of masculinity (and gender) as something we purposively undertake. In these perspectives, masculinity comes to be understood as a relational process for men, something that is "done" or accomplished in the course of social interaction. In this sense, masculinity exists as a set of discursive practices which shapes the way men speak, feel and think. To some extent they are the various discourses that different domains of social life makes available for the construction of masculine identities which determines the kinds of identities they can assume. This is not to say that individuals have no freedom over their identity process. However, this freedom should be understood as a battery between several and sometimes competing discursive resources.

In this study, employing the principles of critical discursive psychological approach (Edley, 2001; Wetherell, Edley, 1999), we seek to investigates the discursive construction of masculinity in digital environment, in order to identify the various resources, in the form of established repertoires, that men use to position themselves in relation to conventional discourses of the masculine, and how masculinity both impinges upon and is transformed by those practices. To do so, we analyze the content of two Facebook Pages dedicated to men's rights issues, called Antisessismo (Antisexism) and Diritti Maschili - Equità e Umanità (Men's rights - Equity and Humanity). We focus on these pages because, even though their participants often perpetuate the same antifeminism rhetoric carried on by conservative men's rights movements, at first sight their anti-sexist discourses seem to reject compulsory gender roles and promote the leftist values of equality and antidiscrimination. In this sense, these groups rely on and use competing discursive repertoires that differ from those of more ideologically oriented groups like Incel or MGTOW. Here, the role of Facebook is significant because it addresses people's feelings of engagement, without necessitating to align with the whole ideological spectrum of men's rights activism.

Using an inductive methodology (Strauss, Corbin 1998), the content of the posts and the user's comments is qualitatively analyzed to find recurring themes and patterns, going back in time from the date of the analysis (April 2019) and moving forward until theoretical saturation is reached. We also conduct a qualitative digital ethnography reading and observing debates.

\section{Results}

Online social networking sites, such as Facebook, have provided a new platform for men to mobilize and rework available discursive repertoires that make themselves comfortable with their male identity. Anti-sexist, anti-feminist, and "pro male" groups give the chance to understand how men dispute and negotiate opinions, beliefs and world views in an attempt to destabilize and/or reaffirm essentialist notions of what is culturally allowed in terms of being man and being woman in our society

Our findings suggest that in these groups, masculinity is rarely negotiated or discussed but it is assumed as a common sense, providing a basis for shared social understandings. However, there is no unitary meaning to this common sense of masculinity, on the contrary, it contains many contradictory or competing arguments. Individuals are 
positioned by discourses in the Foucauldian sense, but, as our data demonstrate, these identity positions are by no means stable and consistent: users can shift between different modes of masculinity and actively re-create positions for themselves, especially in response to "trouble".

On the one hand, although "softer" and apparently "sensitive" styles of masculinity are developing within these online groups, the discursive construction of masculinity seems to reaffirm the masculine ideal of the rational, disembodied subject of the liberal tradition, and ends up perpetuating a normative gender dualism between what the West has characterized as masculine (logic, moral reasoning, conflict, individualism) and what has been, and continues to be, feminized (emotion, collectivity, cooperation, being otheroriented). This confirms how masculinities are often invisible and operate indirectly through discourses of rationality.

On the other hand, if feeling at ease is the quintessential aspect of a masculine stance and constitutive of normative masculinity, men who are nervous and express their emotional discomfort represent a potential break from the reproduction of more conventional forms of masculinity. Many users are not "in sync" with stereotypical male positions and need to seek out other resources in order to construct a different self-reliant subject position. In this sense, social media offer these men a set of feeling rules that they can use to translate their emotional intensities into pleasing and relatable posts, the posts that offer them a way to express their perceived displacement away from the normative and to carve out a new space in relation to changing notions of masculinity.

In this context, regarding such discomfort only as a strategic call for victimhood may be counterproductive. As Gotell and Dutton point out (2016): denial of the realities (though unequal) of men's victimization plays into the vilifying rhetoric of MRAs. Thus, adopting a gender-inclusive view of victimization - overcoming the natural association of masculinity with violence, conceptualizing the violence between men as a gender problem too or accepting the invisibility of men's vulnerabilities as part of a problematic cultural conception of masculinity - may create the potential for moving beyond stagnant theorizations of men as being only either victim of or responsible to various models of masculinity(ies) and masculine practices, and to consider the varied and complex nature men may have with their engagement.

\section{References}


Beasley, C. (2012). Problematizing contemporary Men/Masculinities theorizing: The contribution of Raewyn Connell and conceptual-terminological tensions today, The British Journal of Sociology, 63(4), 747-765.

Berggren, K. (2014). Sticky Masculinity: Post-structuralism, Phenomenology and Subjectivity in Critical Studies on Men. Men and Masculinities, Vol. 17, no 3, p. 231-252

Edley, N. (2001). Analysing masculinity: Interpretative repertoires, ideological dilemmas and subject positions. In Margaret Wetherell, S. Taylor, S. Yates, \& Open University (Eds.), Discourse as data: A guide for analysis. Sage in association with the Open University.

Gotell, L., \& Dutton, E. (2016). Sexual Violence in the 'Manosphere': Antifeminist Men's Rights Discourses on Rape. International Journal for Crime, Justice and Social Democracy, 5, 65.

Strauss, A., Corbin, J. (1998) Basics of Qualitative Research: Techniques and Procedures for Developing Grounded Theory, London, Sage Publications.

Wetherell, M., Edley, N. (2014). A discursive psychological framework for analyzing men and masculinities. Psychology of Men \& Masculinity, 15(4), 355-364. 